\title{
Influence of Foot Massage and Soak Warm Water Feet Against The Edema of Trimester III Pregnant's Woman Leg In Tamansari Public Health Center Tasikmalaya Town
}

\author{
Nurma Nisa Aulia') Siti Saadah²) Sariestya Rismawati3) \\ Nurmanisaaulia72@gmail.com
}

\begin{abstract}
Background : Leg Edema or swelling of the legs found approximately (80\%) In the trimester III of pregnant women. Leg Edema or swelling of the legs is one of the many discomfort found in the trimester III pregnant women, resulting from the blood circulation in the leg. Complementary therapies that can be done to reduce foot edema with foot massage and soak warm water feet. This research aims to determine the influence of foot massage and soak feet with warm water against the edema of trimester III pregnant's woman leg.

Methods : This research uses pre-experimental methods with the design of one group pre-test and posttest. Population of this research is the trimester III of pregnant women with physiological foot edema in Tamansari Public Health Centre area of 620 people, while the samples used as many as 31 people using purposive sampling technique. Test statistics using Wilcoxon test.

Results : The results showed from 31 respondents before the intervention of most edema levels in the 1st degree as much as 21 people $(67.7 \%)$ and after the intervention of most levels of edema in degrees 0 as much as 20 people (64.5\%). Results of data analysis using Wilcoxon test obtained $p$ value $=0.000$, because the value of $P$ value $0.000<0.05$ which means there is influence of foot massage and soak the feet with warm water against the edema of trimester III pregnant's woman leg.

Conclusion : Midwives need to intervene foot massage and soak warm water feet to the trimester III pregnant women.
\end{abstract}

Key Word: foot massage; soak warm water feet; leg edema

1,2,3) Health Polytechnic of Tasikmalaya Midwifery Department

Background. During pregnancy pregnant women experience physical and psychological changes that can cause discomfort, especially trimester II and III such as dyspnea, insomnia, gingivitis and epulison, frequent urination, pressure and discomfort in the perineum, back pain, constipation, varicose veins, fatigue easily, Braxton hicks contractions, leg cramps, ankle edema (non pitting) and mood changes and increased anxiety (Bobak, Lowdermilk and Jensen, 2005) (Perry, Lowdermilk and Wilson, 2013).

Leg Edema or swelling of the legs found approximately (80\%) In the III trimester of pregnant women, as a result of uterine suppression that inhibits venous back flow and gravitational pull causes greater fluid retention (Coban and Sirin, 2010). Edema occurring in pregnancy has many interpretations for example (40\%) Edema encountered in normal pregnancy, (60\%) Edema encountered in pregnancy hypertension (HDK), and (80\%) Occurs in pregnancy hypertension accompanied by proteinuria (pre-Eclampsiaeclampsia) (Prawirohardjo, 2013).
Based on the data of WHO (World Health Organization) year 2007 obtained incidence of vomiting nausea complaints is $80-85 \%$, pain in the back during pregnancy varies between $35-60 \%$, piles occur around (8\%), while swelling occurs around (75\%). In pregnant women the swelling is common in the trimester II and trimester III. From the data above the complaint of swelling occupy the second order $(75 \%)$, edema in pregnant women can be dangerous and can also be harmless. Data from the Ministry of Health of Republic Indonesia on year 2008, (80\%) pregnant women in Indonesia have swollen complaints on the feet, (45\%) In the leg due to infectious diseases such as hypertension, (35\%) because of physiological factors in pregnancy.

According to Arthur C Guyton, edema indicates excessive fluid in the tissues of the body. In many circumstances, edema mainly occurs in the extracellular fluid and can involve intracellular fluid (Guyton \& Hall, 2006). Edema is a swelling caused by the filling of fluid in the body fluids. Half of pregnant women experience swelling in the legs during her 
pregnancy, edema caused by excessive extra blood volume during pregnancy (Morgan and Hamilton, 2009).

The greater the gestational age of mothers, the greater the edema experienced but the edema that occurs is physiological edema caused by the continued rise of the uterus, when edema is increasingly will reduced mother's activity, because the body weight will increase. Edema can occur increasingly severe when the sodium levels are high in the body because the nature of sodium (salt) attracts more water into the bloodstream. When water continues will be attracted and blood vessels widen, blood vessels can rupture and the result of ruptured blood vessels will inhibit nutrient supply to Fetus, when the nutrients are less inhibiting fetal growth (Dewi and Sunarsih, 2011).

Results of preliminary studies conducted by researchers in the work area of Tamansari Public Health Centre in 5 people pregnant mothers, there are 2 pregnant mothers who suffer from leg edema. The way that pregnant women do to overcome edema in his feet by doing light activity on foot, and not knowing other ways that can be done.

Whereas nowadays, it has developed complementary therapies that can be used for pregnant women. Management to reduce edema one way to facilitate blood circulation, namely foot massage and soak warm water feet. One of the benefits of foot massage is to facilitate the circulation in the blood. According to (Coban and Sirin, 2010) In his research shows that foot massage is effective for lowering leg edema in advanced pregnancy.

Soaking the feet with warm water is also beneficial to improve blood circulation and reduce edema (Potter P.A dan Perry G.A., 2006). The research results of (Khedr and Hemida, 2016), indicating that water's immersion can reduce leg edema. This intervention has been used to produce physiological therapeutic effects for pregnant women to maintain health, prevent, and treat diseases.

Based on the above background, the aim of this research is to know the influence of foot massage and soak the feet with warm water on the edema of the feet of the III trimester of pregnant women.

Methods. The method used in this study was a pre-experimental method with the design of one group pre-test and post-Test
(Notoatmodjo, 2010) This research was performed by the working area of Tamansari Public Health Centre in Tasikmalaya town on January-March 2019. The population in this study is trimester III pregnant mother in the working area of Tamansari Public Health Centre. With the sample number of 31 people according to the criteria of inclusion by purposive sampling.

The criteria for inclusion: expectant mothers aged 20-35 years, pregnant women with pregnancy age $>30$ weeks, pregnancy is not accompanied by a disease, pregnant women are not consuming medicines, mothers are not Workers (housewives), and mothers who are willing to become Research respondents.

Data collection was done by first providing informed consent about the research be conducted. The degree measurement of edema performed before and after intervention is administered using a digital timeframe. The intervention was carried out for 30 minutes within 5 consecutive days. The results of data retrieval were performed using univariate analysis and sufficient with Wilcoxon test

\section{Research and Discussion}

Table 1 Distribution frequency number of respondents foot edema in the trimester III pregnant women

\begin{tabular}{lll}
\hline intervention & Frequency & Percentage \\
\hline Before & 31 & 100 \\
After & 31 & 100 \\
\hline
\end{tabular}

Based on the table 1 above shows that the number of respondents were III trimester of pregnant women both before and after the intervention of 31 people (100\%).

Table 2 Overview of degrees of leg edema in the trimester III pregnant women before and after performed foot Massage dan soak warm water feet in the work area of Tamansari Public Health Center.

\begin{tabular}{lllll}
\hline \multirow{2}{*}{ Degrees Edema } & \multicolumn{3}{l}{ Before } & \multicolumn{3}{l}{ After } \\
\cline { 2 - 5 } Feet & F & $\%$ & F & $\%$ \\
\hline 0 & 0 & 0 & 20 & 64,5 \\
1 & 21 & 67,7 & 9 & 29,0 \\
2 & 8 & 25,8 & 2 & 6,5 \\
3 & 2 & 6,5 & 0 & 0 \\
4 & 0 & 0 & 0 & 0 \\
\hline Total & 31 & 100 & 31 & 100 \\
\hline
\end{tabular}

Based on table 2 above shows that the degree of edema of pregnancy is trimester III of 
pregnant women. Before the intervention in the degree of edema 1 as much as 21 people $(67.7 \%)$, the degree of edema 2 as much as 8 people $(25.8 \%)$, and the degree of edema 3 as much as 2 people (6.5\%). After intervention in the degree of edema 0 as much as 20 people $(64.5 \%)$, the degree of edema 1 as much as 9 people $(29.0 \%)$, and the degree of edema 3 as much as 2 people $(6.5 \%)$. This indicates a decrease in the degree of foot edema in the III trimester of pregnant women.

Table 3 The effect of foot massage and soak warm water feet against the edema of the feet of the trimester III pregnant women in the work area of Tamansari public health care after intervention obtained the following results

\begin{tabular}{llll}
\hline Intervention & $\mathrm{N}$ & $\mathrm{Z}$ & $\rho$ value \\
\hline $\begin{array}{l}\text { Before } \\
\text { After }\end{array}$ & 31 & $-4,973$ & 0,000 \\
\hline
\end{tabular}

In the table 3 above shows statistical test results using Wilcoxon test, indicating that the correlation between the two variables is -4.973 with a signification or $\rho$ value of 0.000 . This indicates that the correlation between two variables is strong and significant. Based on a test Wilcoxon obtained $\rho$ value of 0.000 and due to $\rho$ value $0.000<\alpha(0.05)$, then $\mathrm{Ho}$ rejected and $\mathrm{Ha}$ accepted meaning that there is influence of foot massage and soak warm water feet against the edema of the foot of the trimester III pregnant's woman in the work area of Tamansari Public Health Centre.

Foot massage and soak warm water feet is complementary therapy that can be used for pregnant women in reducing edema of one of them by easing blood circulation. If this intervention is carried out routinely, can be a complaint to the swelling of the leg edema of the pregnant women Trimester III.

Foot massage is a massage movement at the foot of only the exfiltration and emphasis in such a way that does not stimulate contraction's occurence. This foot massage is one of treatment of pre-natal massage. According to (Coban and Sirin, 2010) foot massage performed for 20 minutes for 5 days on the feet that experience swelling or edema of the foot in the ankle and legs proved effective. This manipulation activity was done with the right point so it is effective to facilitate blood's circulation on the vascular back (Widi Lestari, Widyawati and Admini, 2017).

Hydrotherapy is the technique of body treatment using the help of water (warm, hot, cold, moisture, ice water) both silent and moving. This intervention has been used to produce physiological therapeutic effects For pregnant women to maintain health, prevent, and treat illness. The water pressure is given uniformly from all sides and pushes the extracellular fluid into the intravascular chamber, resulting in an increase in the central blood volume that can lead to increased uterine blood flow. Increased blood is comparable to female edema (Mooventhan and Nivethitha, 2014).

This was in line with the research of (Khedr and Hemida, 2016) stating that there was an influence on soak water feet that showed significant results (P. < 0.001). The research conducted by (Coban and Sirin, 2010) showed significant results of reducing leg edema.

Conclusion and Suggestions. Based on the results of the analysis that has been performed concluded that there was the influence of foot massage and soak warm water feet on the edema of the birth of the trimester III of pregnant women in the work area of Tamansari Public Health Center with a value of 0.000 and because $\rho$ value $0.000<\alpha$ (0.05), which means there is influence of foot massage and soak warm water feet against the edema of the advice for respondents expected III trimester pregnant mothers can Familiarize yourself with foot massage and soak warm water feet as complementary therapy that pregnant women can use. For educational institutions is be expected be used as a recommendation in providing obstetrician care to solve the problem of edema of the birth of pregnant women trimester III. For further researchers are be expected to do further research using other non-pharmacological means or methods that can reduce the edema of the feet of pregnant women.

Acknowledgements. Thanks to the researchers say to all those who have helped in completing this research.

\section{References}

Bobak, Lowdermilk and Jensen (2005) Keperawatan Maternitas. 4th edn. Edited by Wijayarani and Anugerah. Jakarta: EGC. 
Coban, A. and Sirin, A. (2010) 'Effect of foot massage to decrease physiological lower leg oedema in late pregnancy: A randomized controlled trial in Turkey', International Journal of Nursing Practice, 16(5), pp. 454-60. doi: 10.1111/j.1440172X.2010.01869.

Dewi, V. nanny L. and Sunarsih, T. (2011) Asuhan Kehamilan untuk Kebidanan. Jakarta: Salemba Medika.

Khedr, N. F. H. and Hemida, R. (2016) 'Effect of Leg Elevation versus Water Immersion on Leg Edema in Third Trimester of Pregnancy', IOSR Journal of Nursing and Health Science (IOSR-JNHS), 5(6), pp. 19. doi: 10.9790/1959-0506010109.

Mooventhan, A. and Nivethitha, L. (2014) 'Scientific Evidence Based Effects of Hydrotherapy on Various Systems of the Body', North American Journal of Medical Sciences, 6(5), pp. 199-209. doi: 10.4103/1947.
Morgan, G. and Hamilton, C. (2009) Obstetri \& Ginekologi; Panduan Praktik. Jakarta: EGC.

Notoatmodjo, S. (2010) Metodologi Penelitian Kesehatan. Jakarta: Rineka Cipta.

Perry, S. ., Lowdermilk, M. . and Wilson, D. (2013) Maternal Child Nursing Care. Elsevier Health Sciences.

Potter P.A dan Perry G.A. (2006) Buku Ajar Fundamental Keperawatan. 4th edn. Edited by Y. Asih. Jakarta: EGC.

Prawirohardjo, S. (2013) IImu Kebidanan. Jakarta: Yayasan Bina Pustaka Sarwono Prawirohardjo.

Widi Lestari, T. E., Widyawati, M. N. and Admini, A. (2017) 'Literatur Review: Penerapan Pijat Kaki dan Rendam Air Hangat Campuran Kencur terhadap Edema Kaki lbu Hamil Trimester III Di Wilayah Kerja Puskesmas I Wangon, Banyumas', Jurnal Kebidanan, 8(2), p. 99. doi: 10.31983/jkb.v8i2.3739. 